\title{
Commentary
}

\section{Documenting and tackling the illegal wildlife trade: change and continuity over 40 years}

\author{
E.J. MiLnER-GULLAND
}

$I^{n}$ n October 2018 the UK government hosts a major international governmental conference on tackling the illegal wildlife trade, the latest in a series that it initiated in 2014 with a conference attended by representatives of 50 countries (UK Government, 2014). The strong governmental commitment to this issue is in response to concerns that the illegal wildlife trade is one of the largest global illcit trades, worth an estimated USD 8-10 billion per year (Haken, 2011), and has potential links to organized crime and terrorism (Wyler \& Sheikh, 2013). This estimate excludes fish (USD 5-10 billion) and timber (USD 7 billion). The trade appears to be growing rapidly and to pose a severe threat to a wide range of wildlife, although evidence of impact is patchy and mostly limited to a few high profile species (Challender \& Macmillan, 2014).

This emphasis on illegal wildlife trade as a priority conservation issue is very welcome. The trade is not, however, a new problem. Looking back to past experiences and attempts to address such trade can provide valuable insights for current policy and practice. The focus of Oryx on practical site- and species-focused conservation means that the journal has always had a strong interest in publishing research that explores the drivers and consequences of wildlife use. To mark and contribute to the deliberations of the October 2018 London conference we have compiled 16 of these articles into a virtual issue (https://www.cam bridge.org/core/journals/oryx/virtual-issues), illustrating both the persistent and changing themes in illegal wildlife trade research as represented in Oryx from the 1960s to the present day.

One of our earliest featured articles (Lambert, 1969) illustrates a rather depressing phenomenon: substantial and locally devastating trade in chelonians has been an ongoing theme in Oryx, with articles on the subject appearing regularly, up to the present day (e.g. Morgan \& Chng, 2018). The attention this taxon is receiving in Oryx underlines the need for more attention in both policy and practice.

The journal has a long history of publishing research on the threat of illegal wildlife trade to taxa that don't otherwise receive much attention, such as insects (Small, 2007), Syngnathidae (seahorses \& pipefish; Martin-Smith \&

E.J. Milner-Gulland Department of Zoology, University of Oxford, Oxford, OX12JD, UK. E-mail ej.milner-gulland@zoo.ox.ac.uk
Vincent, 2006) and orchids (Kreziou et al., 2016), and regions beyond the usual suspects of East Africa, China and South-east Asia, such as Eurasia (Kitson \& Nekaris, 2017), the Mediterranean (Kreziou et al., 2016) and South-west Asia (Bashari et al., 2018). Oryx may also be less susceptible to plant-blindness (Balding \& Williams, 2016): another of our featured papers highlights the threat of the bulb trade to wild plant populations (Read, 1989).

Disproportionate attention is given in the media to the threat of illegal wildlife trade to charismatic species. Oryx publishes research on these species too: for example, Parker \& Martin (1983) asked how many elephants were being killed for the ivory trade. Those with longer memories will remember clearly the heated debates, many of which are echoed now, leading up to the CITES Appendix 1 listing of elephants in 1989.

A strong theme throughout is the methodological contributions of Oryx authors. For the illegal wildlife trade there is a lack of robust evidence to underpin policy and practice. Much of this is a result of a general lack of research attention, but appropriate methods are also needed so that the advice given to policy-makers is relevant, accurate and timely. Parker \& Martin (1983) realised this, providing a reality check for overstatements of elephant mortality. They also highlighted the need to see illegal wildlife trade in the context of other threats; a point that is still salient today (Breuer et al., 2016). Parker \& Martin also had the important gift of recognizing when their analyses needed updating in the light of new information, in this case leading to a revised conclusion that the ivory trade remained disconcertingly high. A particular highlight of the methodological articles is Lam et al.'s (2016) analysis of the effect of CITES listing on the seahorse trade in Hong Kong, using a range of approaches to build robust, triangulated evidence for trade that is difficult to investigate. Similarly, Bashari et al. (2018) tackled the challenging topic of understanding the motivations for illegal hunting, using multiple methods to uncover the complexity of illegal wildlife trade.

At the other end of the trade chain, Theng et al. (2018) focus on understanding the motivations of consumers, a growing concern as attention moves from attempts to control supply to encompass demand reduction. This line of research may appear to be a recent development, but one of our earliest featured articles already highlighted the importance of Asian demand for luxury products (Wayre, 
1969). Many important Oryx articles remind us that illegal wildlife trade is not just cross-continental or for satisfying niche or luxury markets: van Vliet et al. (2012) is an excellent representative of articles that document the large-scale trade in bushmeat in Africa, for consumption, and its important role in food security and livelihoods. They also remind us that responses to illegal wildlife trade must be nuanced and evidenced; simple solutions such as blanket bans rarely work in the complex world of illegal wildlife trade, as Cooney \& Jepson (2006) argued. The unresolved and ongoing discourse around the contentious issue of sustainable use is analysed in articles on illegal wildlife trade (e.g. Small, 2007).

Although I have emphasized ongoing concerns, new issues are arising that require novel approaches. One such new issue is the rise in online activity. Oryx has published research on online trade and social media as drivers and indicators of illegal wildlife trade, such as slow loris trade in Turkey (Kitson \& Nekaris, 2017), Madagascan ploughshare tortoise trade in Indonesia (Morgan \& Chng, 2018), and the role of the dark web in illegal wildlife trade (Roberts \& Hernandez-Castro, 2017). Eid \& Handal (2018) were the first in Oryx to look at online evidence of illegal hunting, using the interesting approach of analysing photographs posted on Facebook by hunters.

Illegal wildlife trade is a critical issue for the continued survival of many species, and has been for many years. Over at least 6 decades Oryx has made important contributions to improve our understanding of this issue. It is however interesting to note how current concern has led to a plethora of recent research on this issue; in an unscientific search for this commentary we found 3-4 articles per decade from 1960, five in 2010-2015, 10 in 2016 and 15 in 2017. I hope that the rapid increase in research on illegal wildlife trade is a signal of greater conservation effort, leading to control of the unsustainable illegal trade that threatens the wildlife we all wish to see thrive.

\section{References}

Balding, M. \& Williams, K.J.H. (2016) Plant blindness and the implications for plant conservation. Conservation Biology, 30, 1192-1199.

Bashari, M., Sills, E., Peterson, M.N. \& Cubbage, F. (2018) Hunting in Afghanistan: variation in motivations across species. Oryx, 52, 526-536.
Breuer, T., Maisels, F. \& Fishlock, V. (2016) The consequences of poaching and anthropogenic change for forest elephants. Conservation Biology, 30, 1019-1026.

Challender, D.W.S. \& MacMillan, D.C. (2014) Poaching is more than an enforcement problem. Conservation Letters, 7, 484-494.

Cooney, R. \& Jepson, P. (2006) The international wild bird trade: what's wrong with blanket bans? Oryx, 40, 18-23.

EID, E. \& HandaL, R. (2018) Illegal hunting in Jordan: using social media to assess impacts on wildlife. Oryx, 52, 730-735.

Haken, J. (2011) Transnational Crime in the Developing World. Global Financial Integrity. Https://www.gfintegrity.org/wpcontent/uploads/2014/05/gfi_transnational_crime_high-res.pdf [accessed 24 July 2018].

Kitson, H. \& Nekaris, K.A.I. (2017) Instagram-fuelled illegal slow loris trade uncovered in Marmaris, Turkey. Oryx, 51, 394.

Kreziou, A., de Boer, H. \& Gravendeel, B. (2016) Harvesting of salep orchids in north-western Greece continues to threaten natural populations. Oryx, 50, 393-396.

Lam, J.T.L., Koldewey, H.J., Yasué, M. \& Vincent, A.C.J. (2016) Comparing interview and trade data in assessing changes in the seahorse Hippocampus spp. trade following CITES listing. Oryx, 50, 36-46.

Lambert, M.R.K. (1969) Tortoise drain in Morocco. Oryx, 10, 161-166. Martin-Smith, K.M. \& Vincent, A.C.J. (2006) Exploitation and trade of Australian seahorses, pipehorses, sea dragons and pipefishes (Family Syngnathidae). Oryx, 40, 141-151.

Morgan, J. \& ChnG, S. (2018) Rising internet-based trade in the Critically Endangered ploughshare tortoise Astrochelys yniphora in Indonesia highlights need for improved enforcement of CITES. Oryx, 52, 744-750.

Parker, I.S.C. \& Martin, E.B. (1983) Further insight into the international ivory trade. Oryx, 17, 194-200.

Read, M. (1989) The bulb trade-a threat to wild plant populations. Oryx, 23, 127-134.

Roberts, D.L. \& Hernandez-Castro, J. (2017) Bycatch and illegal wildlife trade on the dark web. Oryx, 51, 393-394.

SMALL, R.D.S. (2007) Becoming unsustainable? Recent trends in the formal sector of insect trading in Papua New Guinea. Oryx, 41, 386-389.

Theng, M., Glikman, J.A. \& Milner-Gulland, E.J. (2018) Exploring saiga horn consumption in Singapore. Oryx, 52, 736-743.

UK Government (2014) London Conference on the Illegal Wildlife Trade, 12-13 February 2014. Declaration. Https://assets.publishing. service.gov.uk/government/uploads/system/uploads/attachment_ data/file/281289/london-wildlife-conference-declaration-140213.pdf [accessed 24 July 2018].

van Vliet, N., Nebesse, C., Gambalemoke, S., Akaibe, D. \& Nasi, R. (2012) The bushmeat market in Kisangani, Democratic Republic of Congo: implications for conservation and food security. Oryx, 46, 196-203.

WAYre, P. (1969) Wildlife in Taiwan. Oryx, 10, 46-56.

W yler, L.S. \& Sheikh, P.A. (2013) International Illegal Trade in Wildlife: Threats and U.S. Policy. Congressional Research Service Report for Congress RL34395. Https://www.files.ethz.ch/isn/100253/ 213005.pdf [accessed 24 July 2018]. 